\title{
STRATEGI PENGEMBANGAN SISTEM PENGELOLAAN AIR LIMBAH DOMESTIK DI WILAYAH PELAYANAN IPAL REGIONAL LAGADAR
}

\author{
Salma Savira Siddik ${ }^{1)}$, Mohamad Rangga Sururi ${ }^{11}$ \\ ${ }^{1)}$ Jurusan Teknik Lingkungan, Institut Teknologi Nasional, Bandung \\ E-mail: rangga@itenas.ac.id
}

\begin{abstract}
Abstrak
Pengembangan sistem pengelolaan air limbah domestik harus didasarkan pada strategi yang tepat. Perencanaan sistem pengelolaan air limbah domestik terdiri dari 7 kecamatan yaitu Kecamatan Bandung Kulon, Babakan Ciparay, Bojongloa Kidul, Dayeuhkolot, Margahayu, Margaasih, dan Cimahi Selatan. Wilayah tersebut ditetapkan sebagai kota inti pengembangan wilayah metropolitan bandung raya. Berdasarkan Rencana Pembangunan Jangka Menengah Nasional (RPJMD) 2020- 2024, akan dilakukan peningkatan akses sanitasi yang layak dengan upaya peningkatan sistem pengelolaan air limbah domestik (SPALD) terpusat di Metropolitan Bandung Raya. Tujuan dari penelitian ini yaitu menentukan strategi pengembangan sistem pengelolaan air limbah domestik di wilayah perencanaan. Penelitian ini dilakukan dengan menggunakan metode analisis SWOT kuantitatif yang mengacu pada pedoman penyusunan rencana induk sistem pengelolaan air limbah dari Kementrian Pekerjaan Umum dan Perumahan Rakyat. Hasil penelitian menunjukkan, terdapat dua strategi pengelolaan air limbah domestik di wilayah perencanaan yaitu strategi selektif dan strategi agresif. Strategi selektif adalah mengembangkan sistem terpusat namun tetap mengoptimalkan sistem setempat yang sudah ada, digunakan pada wilayah yang termasuk kuadran II yaitu Kecamatan Margaasih. Strategi agresif dilakukan dengan mengembangkan sistem terpusat skala kota secara bertahap, digunakan pada wilayah yang termasuk kuadran III yaitu Kecamatan Bandung Kulon, Babakan Ciparay, Bojongloa Kidul, Dayeuhkolot, Margahayu, dan Cimahi Selatan.
\end{abstract}

Kata Kunci: Air Limbah Domestik, Analisis SWOT Kuantitatif, Kuadran, Strategi

\begin{abstract}
Domestic management system development should be based on the right strategy. Planning of domestic management system consists of 7 district Bandung Kulon, Babakan Ciparay, Bojongloa Kidul, Dayeuhkolot, Margahayu, Margaasih, and Cimahi Selatan. The area was designated as the core city for development of Metropolitan Bandung Raya. Based on Rencana Pembangunan Jangka Menengah Nasional (RPJMD) 20202024, there will be increasing access to decent sanitation by efforts to improve domestic wastewater management, offsite systems in Metropolitan Bandung Raya. The purpose of this research was to determined the strategy domestic wastewater management in the planning area. This research was conducted by using the method of analysis SWOT quantitive referring to master plan waste water treatment system from Kementrian Pekerjaan Umum and Perumahan Rakyat. The research results show there are two strategy domestic wastewater management in the planning area, selective strategy and aggressive strategy. The selective strategy is to develop an offsite system but still optimize existing onsite system, system used in the area including quadrant II is Kecamatan Margaasih. The aggressive strategy by gradually develop city-scale offsite system, system used in the area including quadrant III are Kecamatan Bandung Kulon, Babakan Ciparay, Bojongloa Kidul, Dayeuhkolot, Margahayu, dan Cimahi Selatan.
\end{abstract}

Keywords: Analysis SWOT Quantitative, Domestic WasteWater, Quadrant, Strategy 


\section{PENDAHULUAN}

Pertumbuhan jumlah penduduk meningkat seiring dengan meningkatnya kepadatan penduduk dan kebutuhan air bersih. Peningkatan kebutuhan air bersih mengakibatkan tingginya jumlah air limbah yang dihasilkan. Jika tidak dikelola dengan baik, air limbah tersebut dapat menurunkan kualitas badan air, bahkan sumber air baku air minum (Sururi et al., 2019). Sebagai konsekuensi dari turunnya kualitas badan air yaitu menyulitkan proses pengolahan air minum (Sururi et al., 2020).

Dalam Rencana Pembangunan Jangka Menengah Nasional (RPJMN) 2020-2024, akan dilakukan peningkatan akses sanitasi yang layak dengan upaya peningkatan sistem pengelolaan air limbah domestik (SPALD) terpusat di Metropolitan Bandung Raya dan sehubung dengan target ke 7 Millenium Development Goals (MDGs) yaitu "Jaminan keberlanjutan atau kelangsungan lingkungan hidup (Ensure Environmental Sustainability)".

Dinas Perumahan dan Permukiman Provinsi Jawa Barat akan merencanakan sistem pengelolaan air limbah secara terpusat. Salah satunya yaitu membangun IPAL Regional Lagadar. Wilayah Pelayanan IPAL Regional Lagadar ditetapkan sebagai Kota Inti pengembangan wilayah Metropolitan Bandung Raya. Wilayah pelayanan IPAL Regional Lagadar direncanakan melayani 7 kecamatan yaitu Kota Bandung (Kecamatan Bandung Kulon, Kecamatan Babakan Ciparay dan Kecamatan Bojongloa Kidul), Kota Cimahi (Kecamatan Cimahi Selatan), Kabupaten Bandung (Kecamatan Dayeuhkolot, Kecamatan Margahayu, dan Kecamatan Margaasih) (Dinas Perumahan dan Permukiman Provinsi Jawa Barat, 2016). Wilayah tersebut akan menjadi lingkup analisis SWOT kuantitatif.

Berdasarkan kondisi eksisting, dimana pengelolaan air limbah masih menggunakan sistem onsite dan sistem offsite yang belum berfungsi optimal. Terdapat beberapa kondisi lain seperti tingginya kepadatan penduduk dan meningkatnya jumlah penyakit bawaan air (waterborne disesases) dimana prevalensi penyakit diare sebesar 4.715,82 penduduk (Dinas Perumahan dan Permukiman Provinsi Jawa Barat, 2016).

Berdasarkan uraian tersebut, perlu dilakukan penentuan strategi pengembangan sistem pengelolaan air limbah domestik di wilayah perencanaan guna mengurangi pencemaran lingkungan dan potensi penyakit bawaan air. Maksud penelitian ini yaitu melakukan deliniasi 
catchment pelayanan dan melakukan analisis SWOT kuantitatif di wilayah perencanaan. Tujuannya yaitu menentukan strategi pengembangan sistem pengelolaan air limbah domestik di wilayah perencanaan. Penelitian ini merupakan penelitian awal atau baru, dimana wilayah regional masih sangat jarang dilakukan dengan wilayah yang memiliki karakteristik berbedabeda diantara kabupaten/kota.

\section{METODE PENELITIAN}

Tahapan penelitian terdiri dari studi literatur, pengumpulan data sekunder, deliniasi catchment pelayanan serta analisis SWOT kuantitatif. Studi literatur berupa peninjauan literatur-literatur yang berkaitan dalam penentuan strategi pengembangan sistem pengelolaan air limbah domestik. Literatur yang digunakan dapat berupa jurnal, buku, peraturan dan lain sebagainya. Pengumpulan data dibutuhkan dalam penelitian ini. Uraian data sekunder yang digunakan dalam penelitian dapat dilihat pada Tabel 1. Peneliti juga melakukan observasi berupa dokumentasi mengenai kondisi eksisting wilayah perencanaan.

Tabel 1. Uraian Data Sekunder

\begin{tabular}{|c|c|c|}
\hline No. & Data & Sumber \\
\hline 1. & Kepadatan Penduduk & $\begin{array}{l}\text { BPS Kecamatan Bandung Kulon, Babakan Ciparay, Bojongloa } \\
\text { Kidul, Dayeuhkolot, Margahayu, Margaasih, dan Cimahi } \\
\text { Selatan }\end{array}$ \\
\hline 2. & $\begin{array}{lr}\text { Resiko } & \text { Sanitasi, } \\
\text { Permeabilitas } & \text { Tanah, dan } \\
\text { Kedalaman Muka Air Tanah }\end{array}$ & Dinas Perumahan dan Permukiman Provinsi Jawa Barat \\
\hline 3. & Akses Air Minum & $\begin{array}{l}\text { - Dinas Kesehatan Kota Bandung } \\
\text { - DIKPLHD Kabupaten Bandung } \\
\text { - Profil Kesehatan kota Cimahi }\end{array}$ \\
\hline 4. & Kawasan Kumuh & $\begin{array}{l}\text { - SK Kumuh Kota Bandung } \\
\text { - SK Kabupaten Bandung } \\
\text { - SK Kota Cimahi }\end{array}$ \\
\hline 5. & Topografi & Badan Perencanaan Pembangunan Daerah Provinsi Jawa Barat \\
\hline 6. & Kelembagaan & $\begin{array}{l}\text { - SK Kota Bandung } \\
\text { - SK Kabupaten Bandung } \\
\text { - SK Kota Cimahi }\end{array}$ \\
\hline 7. & Kemampuan Pembiayaan & $\begin{array}{l}\text { - RPJMD Kota Bandung Tahun 2018-2023 } \\
\text { - RPJMD Kabupaten Bandung Tahun 2016-2021 } \\
\text { - RPJMD Kota Cimahi Tahun 2017-2022 }\end{array}$ \\
\hline 8. & Tingkat Pendidikan & Dinas Kependudukan dan Pencatatan Sipil Provinsi Jawa Barat \\
\hline
\end{tabular}

Deliniasi catchment pelayanan dilakukan menggunakan software arcgis dan menggunakan data dasar DEM (Digital Elevation Model). dimana dilakukan pembatasan wilayah 
berdasarkan catchment area. Catchment area (Daya tanggapan air) yaitu suatu wilayah daratan yang dibatasi oleh punggung-punggung gunung berdasarkan topografi yang berfungsi menampung, menyimpan dan mengalirkan air hujan ke laut melalui sungai utama (Azwarman, A., 2020). Deliniasi catchment pelayanan dilakukan bertujuan untuk memastikan bahwa pada wilayah perencanaan hanya terdapat satu catchment area.

\subsection{Analisis SWOT Kuantitatif}

Analisis SWOT yaitu menganalisa kondisi internal dan ekternal yang digunakan dalam merancang strategi dan program kerja pada suatu organisasi. Analisis internal terdiri dari penilaian terhadatp faktor kekuatan (strength) dan kelemahan (weakness). Sedangkan analisis eksternal terdiri dari penilaian terhadap faktor peluang (opportunity) dan tantangan (threat) (Wicaksono, 2017). Tahapan dalam menganalisis SWOT kuantitatif yaitu penentuan parameter penting skoring, kemudian analisis faktor internal dan eksternal dengan metode skoring, lalu hasil skoring akan diplot pada matrik untuk menentukan posisi kuadran. Penentuan parameter penting dilakukan untuk mempermudah dalam menganalisis SWOT kuantitatif. Pada penentuan parameter, klasifikasi skoring dibagi menjadi 4 kelompok skor yaitu skor 1,2, 3 dan 4. Klasifikasi skoring tersebut berdasarkan pada skor EHRA resiko sanitasi yang terbagi menjadi 4 skor. Sehingga semua parameter akan dikelompokkan menjadi 4 kelompok skor, dimana nilai skor tersebut akan dikalkulasikan pada analisis faktor internal dan eksternal. Hasil analisis terhadapat nilai skor untuk setiap parameter skoring yaitu sebagai berikut .

\section{A. Kepadatan Penduduk}

Penentuan skoring untuk kepadatan penduduk mengacu pada direktorat jendral bina konstruksi dan PerMenPR No. 32 Tahun 2006. Skoring parameter kepadatan penduduk dapat dilihat pada Tabel 2 .

Tabel 2. Skoring Parameter Kepadatan Penduduk

\begin{tabular}{lc}
\hline \multicolumn{1}{c}{ Parameter } & Skor \\
\hline Kepadatan Penduduk $<50 \mathrm{jiwa} / \mathrm{Ha}$ & 1 \\
\hline Kepadatan Penduduk 50-150 Jiwa/Ha & 2 \\
\hline Kepadatan Penduduk $150-250 \mathrm{jiwa} / \mathrm{Ha}$ & 3 \\
\hline Kepadatan Penduduk $>250 \mathrm{jiwa} / \mathrm{Ha}$ & 4 \\
\hline
\end{tabular}




\section{B. Resiko Sanitasi}

Penentuan skoring untuk resiko sanitasi berdasarkan pada skor EHRA. Kategori resiko sanitasi air limbah di wilayah perencanaan bervariasi dari beresiko rendah hingga sangat tinggi. Skoring parameter resiko sanitasi dapat dilihat pada Tabel 3.

Tabel 3. Skoring Parameter Resiko Sanitasi

\begin{tabular}{lc}
\hline \multicolumn{1}{c}{ Parameter } & Skor \\
\hline Beresiko Rendah (Skor EHRA 1) & 1 \\
\hline Beresiko Sedang (Skor EHRA 2) & 2 \\
\hline Beresiko Tinggi (Skor EHRA 3) & 3 \\
\hline Beresiko Sangat Tinggi (Skor EHRA 4) & 4 \\
\hline
\end{tabular}

\section{Akses Air Minum}

Penentuan skoring untuk akses air minum dari presentase sebesar $<71,05 \%$ hingga $100 \%$. Presentase akses air minum 100\% sehubungan dengan target RPJMN 2020-2024 yaitu 100\% hunian memiliki akses air minum layak termasuk 15\% aman dengan 30\% hunian memiliki akses air minum perpipaan. Skoring parameter akses air minum dapat dilihat pada Tabel 4.

Tabel 4. Skoring Parameter Akses Air Minum

\begin{tabular}{lc}
\hline \multicolumn{1}{c}{ Parameter } & Skor \\
\hline Akses air minum $<71,05-72,03 \%$ & 1 \\
\hline Akses air minum 72,04-77,99\% & 2 \\
\hline Akses air minum 78-99\% & 3 \\
\hline Akses air minum $100 \%$ & 4 \\
\hline
\end{tabular}

\section{Kawasan Kumuh}

Penentuan skoring untuk kawasan kumuh mengacu pada SK Kumuh Kota Bandung, Kabupaten Bandung, dan Kota Cimahi dengan kategori kumuh rendah hingga tinggi. Skoring parameter kawasan kumuh dapat dilihat pada Tabel 5.

Tabel 5. Skoring Parameter Kawasan Kumuh

\begin{tabular}{lc}
\hline \multicolumn{1}{c}{ Parameter } & Skor \\
\hline Bebas Kawasan Kumuh & 1 \\
\hline Kumuh Rendah & 2 \\
\hline Kumuh Sedang & 3 \\
\hline Kumuh Tinggi & 4 \\
\hline
\end{tabular}




\section{E. Topografi}

Penentuan skoring parameter topografi berdasarkan kemiringan lereng, dimana peta kontur di wilayah perencanaan diolah terlebih dahulu menggunakan software arcgis untuk mengetahui kemiringan lereng di wilayah perencanaan. Skoring parameter kawasan kumuh dapat dilihat pada Tabel 6.

Tabel 6. Skoring Parameter Topografi

\begin{tabular}{lc}
\hline \multicolumn{1}{c}{ Parameter } & Skor \\
\hline Kemiringan Lereng 0-2\% & 1 \\
\hline Kemiringan Lereng 2-8\% & 2 \\
\hline Kemiringan Lereng 8-15\% & 3 \\
\hline Kemiringan Lereng 15-25\% & 4 \\
\hline
\end{tabular}

\section{F. Permeabilitas Tanah}

Penentuan skoring untuk permeabilitas tanah mengacu pada klasifikasi menurut uhland dan o'neil. Permeabilitas tanah tergantung berdasarkan jenis tanah dan bantuan yang memiliki nilai permeabilitas $10^{-1}-10^{-5} \mathrm{~cm} / \mathrm{dtk}$. Skoring parameter permeabilitas tanah dapat dilihat pada Tabel 7.

Tabel 7. Skoring Parameter Permeabilitas Tanah

\begin{tabular}{lc}
\hline \multicolumn{1}{c}{ Parameter } & Skor \\
\hline Permeabilitas Cepat & 1 \\
\hline Permeabilitas Agak Cepat & 2 \\
\hline Permeabilitas Sedang & 3 \\
\hline Permeabilitas Lambat & 4 \\
\hline
\end{tabular}

\section{G. Kedalaman Muka Air Tanah}

Penentuan skoring untuk kepadatan penduduk mengacu pada direktorat tata lingkungan dan kawasan pertambangan. Skoring parameter kedalaman muka air tanah dapat dilihat pada Tabel 8.

Tabel 8. Skoring Parameter Kedalaman Muka Air Tanah

\begin{tabular}{lc}
\hline \multicolumn{1}{c}{ Parameter } & Skor \\
\hline Kedalaman muka air tanah $20-30 \mathrm{~m}$ & 1 \\
\hline Kedalaman muka air tanah $10-20 \mathrm{~m}$ & 2 \\
\hline Kedalaman muka air tanah 5-10 m & 3 \\
\hline Kedalaman muka air tanah $<5 \mathrm{~m}$ & 4 \\
\hline
\end{tabular}




\section{H. Kelembagaan}

Kelembagaan berperan penting dalam terpenuhinya sarana sanitasi masyarakat seperti pada tahap persiapan, operasional, pemeliharaan maupun monitoring atau memastikan sistem pengelolaan air limbah beroperasi dengan baik. Skoring parameter kelembagaan dapat dilihat pada Tabel 9.

Tabel 9. Skoring Parameter Kelembagaan

\begin{tabular}{lc}
\hline \multicolumn{1}{c}{ Parameter } & Skor \\
\hline $\begin{array}{l}\text { Tidak ada instansi yang mengelola air } \\
\text { limbah }\end{array}$ & 1 \\
\hline $\begin{array}{l}\text { Akan direncanakan adanya instansi yang } \\
\text { mengelola air limbah }\end{array}$ & 2 \\
\hline $\begin{array}{l}\text { Adanya instansi yang mengelola air } \\
\text { limbah }\end{array}$ & 3 \\
\hline $\begin{array}{l}\text { Adanya instansi yang mengelola air } \\
\text { limbah dan UPTD khusus yang } \\
\text { melaksanakan kegiatan teknis } \\
\text { pengelolaan air limbah }\end{array}$ & 4 \\
\hline
\end{tabular}

\section{Kemampuan Pembiayaan}

Kemampuan pembiayaan berperan dalam memenuhi biaya pengoperasian dan pemeliharaan suatu sistem pengelolaan air limbah agar dapat berjalan dengan baik. Skoring parameter kemampuan pembiayaan dapat dilihat pada Tabel 10.

Tabel 10. Skoring Parameter Kemampuan Pembiayaan

\begin{tabular}{lc}
\hline \multicolumn{1}{c}{ Parameter } & Skor \\
\hline $\begin{array}{l}\text { Tidak ada anggaran untuk sistem } \\
\text { pengelolaan air limbah }\end{array}$ & 1 \\
\hline $\begin{array}{l}\text { Akan direncanakan adanya } \\
\text { anggaran untuk sistem pengelolaan } \\
\text { air limbah }\end{array}$ & 2 \\
\hline $\begin{array}{l}\text { Adanya anggaran untuk sistem } \\
\text { pengelolaan air limbah }\end{array}$ & 3 \\
\hline $\begin{array}{l}\text { Adanya anggaran untuk sistem } \\
\text { pengelolaan air limbah dan sudah } \\
\text { direncanakan anggaran untuk 5 } \\
\text { tahun kedepan }\end{array}$ & 4 \\
\hline
\end{tabular}




\section{J. Peraturan Daerah}

Peraturan daerah berperan sebagai regulator yang mengatur sistem pengelolaan air limbah di suatu wilayah dalam meningkatkan kondisi sanitasi sehingga kondisi kesehatan masyarakat dan lingkungan sekitar akan menjadi baik. Skoring parameter peraturan daerah dapat dilihat pada Tabel 11.

Tabel 11. Skoring Parameter Peraturan Daerah

\begin{tabular}{lc}
\hline \multicolumn{1}{c}{ Parameter } & Skor \\
\hline $\begin{array}{l}\text { Tidak ada peraturan daerah kota terkait } \\
\text { pengelolaan air limbah domestik }\end{array}$ & 1 \\
\hline $\begin{array}{l}\text { Tidak ada peraturan daerah kota terkait } \\
\text { pengelolaan air limbah domestik, } \\
\text { namun mengacu pada peraturan } \\
\text { menteri pekerjaan umum dan } \\
\text { perumahan rakyat }\end{array}$ & 2 \\
\hline $\begin{array}{l}\text { Tidak ada peraturan daerah kota terkait } \\
\text { pengelolaan air limbah domestik, } \\
\text { namun mengacu pada peraturan daerah } \\
\text { provinsi }\end{array}$ & 3 \\
\hline $\begin{array}{l}\text { Adanya peraturan daerah kota terkait } \\
\text { pengelolaan air limbah domestik }\end{array}$ & \\
\hline
\end{tabular}

\section{K. Tingkat Pendidikan}

Tingkat pendidikan berpengaruh pada kemampuan masyarakat dalam retribusi pengelolaan air limbah domestik. Skoring parameter peraturan daerah dapat dilihat pada Tabel 12.

Tabel 12. Skoring Parameter Tingkat Pendidikan

\begin{tabular}{lc}
\hline \multicolumn{1}{c}{ Parameter } & Skor \\
\hline $\begin{array}{l}\text { Tidak/belum sekolah dan belum tamat } \\
\text { SD }\end{array}$ & 1 \\
\hline SD, SMP dan SMA & 2 \\
\hline D1/D2 dan D3 & 3 \\
\hline S1, S2, dan S3 & 4 \\
\hline
\end{tabular}

\section{ANALISIS DAN PEMBAHASAN}

\subsection{Gambaran Umum}

Topografi di wilayah perencanaan beragam mulai dari dataran maupun berbukit. Topografi terendah berada di Kecamatan Dayeuhkolot yang memiliki ketinggian 662,5 meter diatas 
permukaan laut yang sebagian besar berupa dataran, sedangkan topografi tertinggi berada di Kecamatan Cimahi Selatan, Kelurahan Cibeber yang memiliki ketinggian 750 meter diatas permukaan laut (BPS Kecamatan Cimahi Selatan, 2019).

Kepadatan penduduk di wilayah perencanaan bervariasi. Kepadatan penduduk di wilayah perencanaan tertinggi berada di Kecamatan Bandung Kulon sebesar 220,71 jiwa/Ha, Sedangkan kepadatan penduduk terendah berada di Kecamatan Margaasih sebesar 47,52 jiwa/Ha. Daerah dengan kepadatan penduduk yang tinggi akan lebih diprioritaskan menggunakan sistem pengelolaan air limbah dengan perpipaan. Dikarenakan potensi pencemaran air tanah di daerah tersebut akan lebih tinggi (sumber) Kepadatan penduduk di wilayah perencanaan dapat dilihat pada Tabel 13.

Tabel 13. Kepadatan Penduduk di Wilayah Perencanaan Tahun 2018

\begin{tabular}{lc}
\hline \multicolumn{1}{c}{ Kecamatan } & $\begin{array}{c}\text { Kepadatan Penduduk } \\
\text { (Jiwa/Ha)* }\end{array}$ \\
\hline Bandung Kulon & 220,706 \\
\hline Babakan Ciparay & 158,832 \\
\hline Bojongloa Kidul & 159,367 \\
\hline Dayeuhkolot & 119,507 \\
\hline Margahayu & 175,856 \\
\hline Margaasih & 47,522 \\
\hline Cimahi Selatan & 211,933 \\
\hline
\end{tabular}

Sumber: Badan Pusat Statistik 2019 setiap Kecamatan

Sumber air minum di wilayah perencanaan dibagi menjadi 2 yaitu sumber air minum bukan perpipaan yang terdiri dari sumur gali, sumur BOR, serta terminal air dan sumber air minum perpipaan yang terdiri dari mata air terlindung dan PDAM. Jumlah penduduk yang memiliki akses minum tertinggi terdapat di Kecamatan Margaasih yaitu 119.151 jiwa sebesar 83,08\% terlayani air minum (Dokumen Informasi Kinerja Lingkungan Hidup Daerah Kabupaten Bandung, 2018). Jumlah penduduk yang memiliki akses air minum di wilayah perencanaan dapat dilihat pada Tabel 14 . 
Tabel 14. Penduduk Yang Memiliki Akses Air Minum di Wilayah Perencanaan

\begin{tabular}{lcc}
\hline \multirow{2}{*}{\multicolumn{1}{c}{ Kecamatan }} & \multicolumn{2}{c}{$\begin{array}{c}\text { Penduduk yang Memiliki } \\
\text { Akses Air Minum }\end{array}$} \\
\cline { 2 - 3 } & Jumlah & \% \\
\hline Bandung Kulon $^{(\mathbf{1})}$ & 93.316 & 70,78 \\
\hline Babakan Ciparay $^{(\mathbf{1})}$ & 108.564 & 79,20 \\
\hline Bojongloa Kidul $^{(\mathbf{1})}$ & 63.940 & 71,17 \\
\hline Dayeuhkolot $^{(\mathbf{2})}$ & 101.102 & 73,29 \\
\hline Margahayu $^{(\mathbf{2})}$ & 109.101 & 77,29 \\
\hline Margaasih $^{(\mathbf{2})}$ & 119.151 & 83,08 \\
\hline Cimahi Selatan $^{(\mathbf{3})}$ & 188.200 & 75,37 \\
\hline
\end{tabular}

Sumber: (1) Dinas Kesehatan Kota Bandung, 2018

(2) DIKPLHD Kabupaten Bandung, 2018

(3) Profil Kesehatan Kota Cimahi, 2017

\subsection{Deliniasi Catchment Pelayanan}

Deliniasi catchment pelayanan dilakukan dengan beberapa tahapan yaitu fill DEM (mengisi sink), flow direction (arah aliran permukaan), flow accumulation (pola aliran sungai), Stream Order (ordo sungai), stream to features (konversi stream order menjadi features berupa polygon), hingga mendapatkan basin atau catchment pelayanan. Setelah dilakukan deliniasi catchment pelayanan didapatkan 5 kelompok catchment yang terdiri dari catchment 1, catchment 2, catchment 3 , catchment 4 , dan catchment 5 . Hasil deliniasi catchment pelayanan dapat dilihat pada Gambar 1.

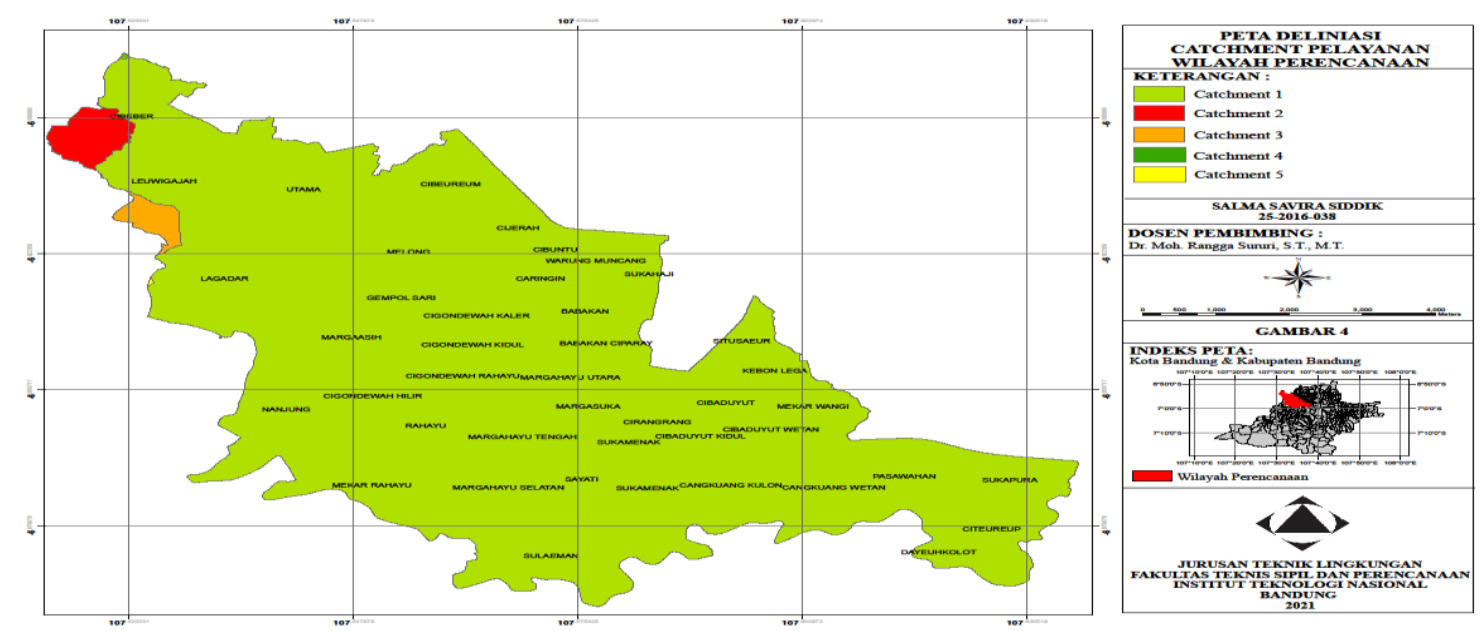

Gambar 1. Peta Catchment Pelayanan di Wilayah Perencanaan

(Sumber: Hasil Analisa, 2020)

Berdasarkan peta deliniasi catchment pelayanan terdapat satu catchment terluas yaitu catchment 1. Catchment tersebut akan menjadi lingkup dari analisis SWOT kuantitatif, karena 
pada analisis hanya akan berfokus pada satu cathment terluas. Sehingga Kelurahan Cibeber, Leuwigajah, dan Lagadar tidak akan masuk dalam lingkup analisis SWOT kuantitatif.

\subsection{Analisis Faktor Internal dan Eksternal}

Analisis faktor internal dilakukan dengan mengidentifikasi kelemahan dan kekuatan yang ada di wilayah perencanaan. Sedangkan analisis faktor eksternal dilakukan dengan mengidentifikasi peluang dan ancaman yang akan mempengaruhi sistem pengelolaan air limbah domestik kedepannya. Analisis faktor internal dan eksternal dibuat dalam bentuk tabel dengan metode skoring. Analisis faktor internal dan eksternal dilakukan berdasarkan masingmasing kecamatan di wilayah perencanaan. Analisis faktor internal dan eksternal di Kecamatan Bandung Kulon dapat dilihat pada Tabel 15. Hasil analisis faktor internal dan eksternal masing-masing kecamatan dapat dilihat pada Tabel 16.

Tabel 15. Analisis Faktor Internal dan Eksternal Kecamatan Bandung Kulon

\begin{tabular}{|c|c|c|}
\hline No & Parameter & Skor \\
\hline \multicolumn{3}{|c|}{ Kekuatan } \\
\hline 1. & Memiliki kepadatan penduduk 220,706 jiwa/Ha & 3 \\
\hline 2. & Termasuk resiko sanitasi beresiko sangat tinggi & 4 \\
\hline 3. & Termasuk kawasan kumuh sedang & 3 \\
\hline 4. & Memiliki kedalaman muka air tanah 2-3 m & 4 \\
\hline Jumla & iilai kekuatan (Strength) & 14 \\
\hline \multicolumn{3}{|c|}{ Kelemahan } \\
\hline 1. & Memiliki akses air minum sebesar 70,78\% & 1 \\
\hline 2. & Memiliki kemiringan lereng 0-2\% & 1 \\
\hline 3. & Memiliki permeabilitas tanah $10^{-3}-10^{-7} \mathrm{~m} / \mathrm{dtk}$ & 1 \\
\hline Jumla & iilai kelemahan (Weakness) & 3 \\
\hline Selisi & ilai kekuatan-kelemahan & 11 \\
\hline \multicolumn{3}{|c|}{ Peluang } \\
\hline 1. & $\begin{array}{l}\text { Adanya anggaran untuk sistem pengelolaan air } \\
\text { limbah dan sudah direncanakan anggaran untuk } 5 \\
\text { tahun kedepan }\end{array}$ & 4 \\
\hline 2. & Adanya instansi yang mengelola air limbah & 3 \\
\hline Jumla & iilai peluang (Opportunities) & 7 \\
\hline \multicolumn{3}{|c|}{ Ancaman } \\
\hline 1. & $\begin{array}{l}\text { Tidak ada peraturan daerah kota terkait pengelolaan } \\
\text { air limbah domestik, namun mengacu pada } \\
\text { peraturan menteri pekerjaan umum dan perumahan } \\
\text { rakyat }\end{array}$ & 2 \\
\hline 2. & Pendidikan terakhir paling banyak yaitu SMA & 2 \\
\hline Jumla & iilai ancaman (Threats) & 4 \\
\hline Selisi & ilai peluang-ancaman & 3 \\
\hline
\end{tabular}

(Sumber: Hasil Analisis, 2020) 
Tabel 16. Hasil analisis faktor internal dan eksternal masing-masing kecamatan

\begin{tabular}{clcc}
\hline No. & Kecamatan & $\begin{array}{c}\text { Selisih kekuatan dan } \\
\text { kelemahan }\end{array}$ & $\begin{array}{c}\text { Selisih peluang dan } \\
\text { ancaman }\end{array}$ \\
\hline 1. & Babakan Ciparay & 9 & 3 \\
\hline 2. & Bojongloa Kidul & 12 & 3 \\
\hline 3. & Dayeuhkolot & 5 & 4 \\
\hline 4. & Margahayu & 5 & 4 \\
\hline 5. & Margaasih & -1 & 4 \\
\hline 6. & Cimahi Selatan & 10 & 10 \\
\hline
\end{tabular}

(Sumber: Hasil Analisis, 2020)

\subsection{Penentuan Posisi Kuadran}

Penentuan posisi kuadran pengelolaan air limbah berdasarkan hasil selisih faktor internal dan eksternal sebagai koordinat sumbu x dan y. Hasil analisis faktor internal dan eksternal di plot pada matrik SWOT. Matrik SWOT terdapat pada Gambar 2.

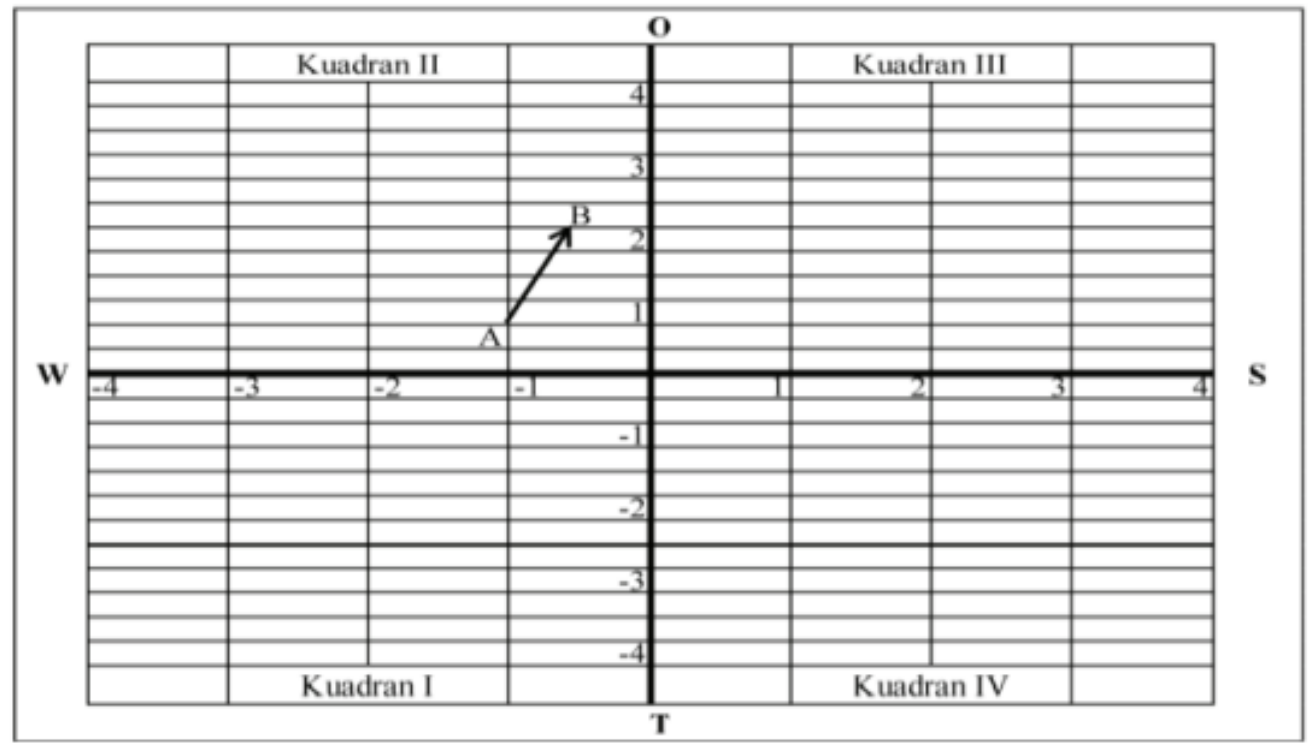

Gambar 2. Matrik SWOT

(Sumber: RISPAL, 2016)

Penentuan posisi kuadran dilakukan berdasarkan masing-masing kecamatan di wilayah perencanaan. Berdasarkan hasil analisis faktor internal dan eksternal menunjukkan selisih faktor kekuatan dan kelemahan bernilai 11 maka sumbu x berada pada garis kekuatan (+), Sedangkan selisih peluang dan ancaman bernilai 3 maka sumbu y berada pada garis peluang (+). Posisi kuadran pengelolaan air limbah di Kecamatan Bandung Kulon pada Gambar 3. 


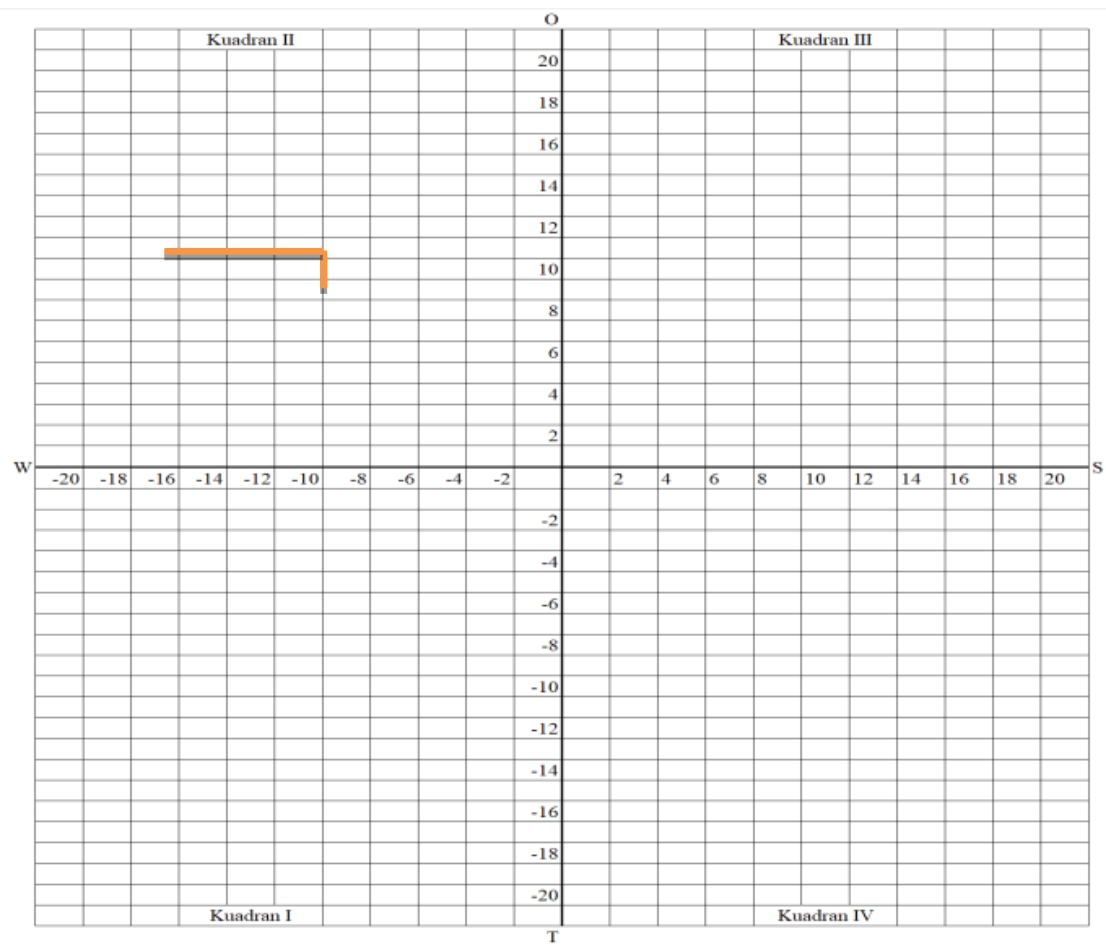

Gambar 3. Posisi Kudaran Kecamatan Bandung Kulon

(Sumber: Hasil Analisa, 2020)

Posisi kuadran pengelolaan air limbah di Kecamatan Bandung Kulon berada di kuadran III. Posisi ini menunjukkan pengelolaan air limbah sudah kuat dan sangat berpeluang untuk dikembangkan. Sehingga strategi yang digunakan yaitu strategi agresif dengan mengembangkan sistem terpusat skala kota yang ditingkatkan secara bertahap (Pedoman RISPAL, 2016). Kecamatan Babakan Ciparay, Bojongloa Kidul, Margahayu, dan Cimahi Selatan juga berada di kuadaran III.

Kecamatan Margaasih berada di kuadran II, hal ini dikarenakan selisih faktor kekuatan dan kelemahan bernilai -1 sehingga sumbu x berada pada garis kelemahan (-). Sedangkan selisih peluang dan ancaman bernilai 4 sehingga sumbu y berada pada garis peluang $(+)$. Posisi Kuadran II menunjukkan pengelolaan air limbah berpeluang untuk dikembangkan walaupun kondisinya masih lemah. Sehingga strategi yang digunakan yaitu strategi selektif dengan mengembangkan sistem terpusat namun tetap mengoptimalkan sistem setempat yang sudah ada. Pada strategi ini adanya perubahan sistem setempat menjadi terpusat (Pedoman RISPAL, 2016). Berdasarkan hasil penentuan posisi kuadran pada masing-masing kecamatan, maka dilakukan pemetaan rekapitulasi hasil analisis SWOT kuantitatif pada Gambar 4. 


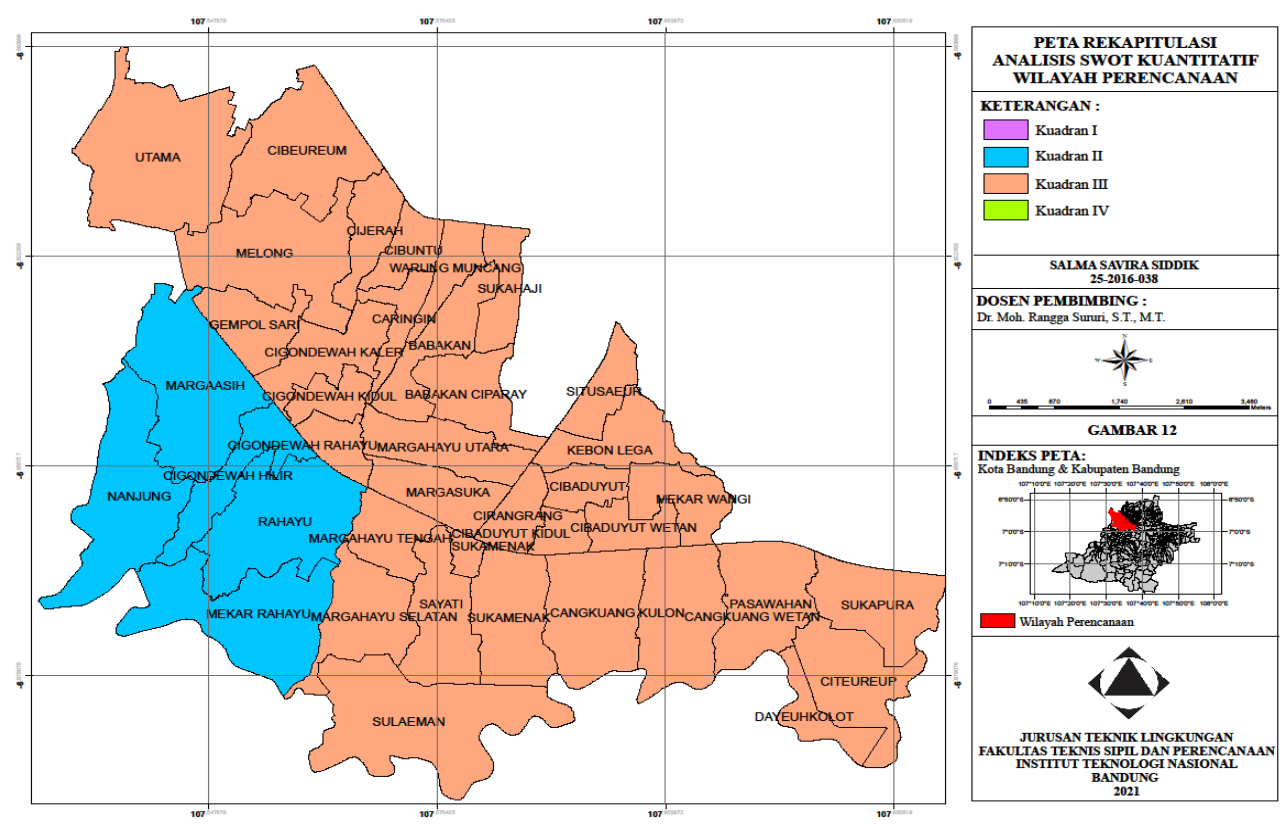

Gambar 4. Peta Rekapitulasi Analisis SWOT Kuantitatif di Wilayah Perencanaan (Sumber: Hasil Analisa, 2020)

\section{KESIMPULAN}

Berdasarkan hasil analisis SWOT, Posisi kuadran di wilayah perencanaan yaitu kuadran II untuk Kecamatan Margaasih dan kudran III untuk Kecamatan Bandung Kulon, Babakan Ciparay Bojongloa Kidul, Dayeuhkolot, Margahayu, dan Cimahi Selatan. Strategi yang digunakan pada kuadran II yaitu strategi selektif dengan mengembangkan sistem terpusat, namun tetap mengoptimalkan sistem setempat yang sudah ada. Sistem terpusat yang digunakan yaitu skala kawasan. Sedangkan strategi yang digunakan pada kuadran III yaitu strategi agresif dengan mengembangkan sistem terpusat skala kota yang ditingkatkan secara bertahap.

\section{DAFTAR PUSTAKA}

Azwarman, A. (2020). Kajian Kapasitas Tampungan Penyimpanan Air di Catchment Area Danau Sipin. Jurnal Civronlit Unbari, 5(1) : 1-8.

Badan Perencanaan Daerah Kota. (2015). Penyusunan Pemutakhiran Strategi Sanitasi Kota Bandung. Kota Bandung.

Badan Perencanaan Daerah Kota. (2016). Penyusunan Strategi Sanitasi Kabupaten Bandung 2016-2020. Kabupaten Bandung.

Dinas Perumahan dan Permukiman Provinsi Jawa Barat. (2016). Laporan Akhir Review 
Rencana Induk Air Limbah Domestik Perkotaan di Metropolitan Bandung Raya.

Dokumen Informasi Kinerja Lingkungan Hidup Daerah Kabupaten Bandung. (2018). Buku II

Laporan Utama Informasi Kinerja Pengelolaan Lingkungan Hidup Daerah Kabupaten

Bandung Tahun 2018.

Kecamatan Cimahi Selatan Dalam Angka. (2019). BPS Kecamatan Cimahi Selatan, Kota Cimahi.

Pedoman Penyusunan Rencana Induk Sistem Pengelolaan Air Limbah. (2016). Tahapan Penyusunan Rencana Induk Sistem Pengelolaan Air Limbah Bagian A.

Peraturan Daerah Kabupaten Bandung No. 27 Tahun 2016 tentang Rencana Tata Ruang

Wilayah Kabupaten Bandung Tahun 2016-2036.

Peraturan Daerah Kota Bandung No. 18 Tahun 2011 tentang Rencana Tata Ruang Wilayah Kota Bandung Tahun 2011-2031.

Peraturan Daerah Kota Cimahi No. 4 Tahun 2013 tentang Rencana Tata Ruang Wilayah Kota Cimahi Tahun 2012-2032.

Peraturan Menteri PUPR No. 2 Tahun 2016 tentang Peningkatan Kualitas Terhadap Perumahan Kumuh dan Permukiman Kumuh.

Peraturan Menteri PUPR No. 4 Tahun 2017 tentang Penyelenggaraan Sistem Pengelolaan Air Limbah Domestik.

Peraturan Menteri PR No. 32 Tahun 2006 tentang Teknis Kawasan Siap Bangun dan Lingkungan Siap Bangun yang Berdiri Sendiri.

Rencana Pembangunan Jangka Menengah Nasional (RPJMN) tahun 2020-2024

Dinas Kesehatan, Pemerintah Kota Cimahi. (2017). Profil Kesehatan Kota Cimahi.

Purwoko, S. (2018). Indikator Air Layak Minum dan Sanitasi Layak dalam Mendukung Upaya Kesehatan Lingkungan di Rumah Tinggal. In Proceeding National Seminar Germas 2018, 1 (1).

Sururi, M. R., Notodarmojo, S., and Roosmini, D. (2019). Aquatic Organic Matter Characteristics And Thmfp Occurrence In A Tropical River. International Journal, 17(62) : 203-211.

Sururi, M. R., Notodarmojo, S., Roosmini, D., Putra, P. S., Maulana, Y. E., and Dirgawati, M. (2020). An Investigation of a Conventional Water Treatment Plant in Reducing Dissolved Organic Matter and Trihalomethane Formation Potential from a Tropical 
River Water Source. Journal of Engineering \& Technological Sciences, 52(2).

Syafri, S.H. (2015). Identifikasi Kemiringan Lereng di Kawasan Permukiman Kota Manado Berbasis SIG. Spasial, 1(1) :70-79.

Wicaksono, A. (2017). Strategi Pemasaran dengan Menggunakan Analisis SWOT Tanpa Skala Industri Pada PT X di Jakarta. Jurnal Manajemen industri dan logistik, 1(2): 192201. 